\title{
Increase of road tunnels safety using Tunnel Traffic \& Operation Simulator
}

\author{
Eva Jančaříková ${ }^{1, *}$, Peter Danišovič ${ }^{1}$, and Juraj Šámek $^{1}$ \\ ${ }^{1}$ University of Žilina, Faculty of Civil Engineering, Department of Construction Management, \\ Univerzitná 8215/1, 01026 Žilina, Slovakia
}

\begin{abstract}
Tunnels, constructions used to shorten transport routes and to improve road safety, are specific engineering structures where the safe operation is very important. Tunnel Traffic \& Operation Simulator (Simulator) was created as a solution of research task focused on increasing safety in road tunnels within the framework of the project "Centre of Transport Research (CVD)" funded by European Regional Development Fund (ERDF). The Simulator is located on Faculty of Civil Engineering of the University of Žilina (Slovakia) and is adapted to control the tunnel in two operator's mode which are functionally convertible. They can during the operation of the simulator control the tunnel's technology and operation in normal conditions and in exceptional situations. Thanks to this, they could work under the pressure with non-performance threat to the tunnel technology and safety of their users. The coordinator checks and assesses the correctness of their conduct.
\end{abstract}

\section{Centre of Transport Research}

The objective of this project, Centre of Transport Research (CVD), is to increase economic efficiency at the macrolevel in transport through direct cooperation of VÚD Žilina (Transport Research Institute, Žilina) and University of Žilina. Responsible workplace is a Department of Construction Management of Faculty of Civil Engineering at the University of Žilina [1].

Transport Research Institute is an organization of science and research with a long tradition and the main area of activity is the organization of research in transport.

The history of the University of Žilina (UNIZA) began on 1 September 1953 when the University of Railway Transport was founded by separating from the Czech Technical University in Prague. It gradually became an important pillar of education in the fields of transport, which resulted in the change in the name to the University of Transport. It was moved to Žilina in 1960 where it underwent many transformations, and in 1980 it was renamed again to the University of Transport and Communications. Later in 1996, it was renamed the University of Žilina. Currently, University consists of 7 faculties, scientific and educational institutes and centres and has approximately 1,500 employees. Faculty of

* Corresponding author: eva.jancarikova@,fstav.uniza.sk 
Civil Engineering has 12 departments and each department is focused on scientific research activities [2].

Specific objectives and activities of the project:

- Applied research of new technologies to improve operational safety of road tunnels.

- Expansion planned research of advanced technologies in the field of law enforcement in road transport.

- Completion of the research activities on innovative approaches to measuring physical and chemical properties of road signs.

- Increasing the rate of research activities in the field of land fragmentation by transport infrastructure on progressive technologies.

The first specific objective includes instrumental and technological workplace building and its commissioning, applied research and integration in the field of road tunnels operations management, system's calibration and then extraction and processing of data for the increase of road tunnels safety and prediction models as a tool for safety improving in road tunnels operation.

\section{Tunnel traffic \& operation simulator}

This research site for road tunnels operation is realized as a real operator's workplace. It shows virtual $1 \mathrm{~km}$ long highway two-tube tunnel [1]. The main objectives of the simulator are:

- Increase of transport's safety in road tunnels.

- The testing possibility of different scenarios in tunnel

- Collection and processing of data from tunnels operation, risk analysis.

- The creation of prediction models

- New knowledge attainment for new tunnels project.

Basic composition of the Simulator consists from central control system (CCS - part of automatic tunnel equipment control), manual control module (MCM - part of manual control as separated module, it serves to a manual tunnel operation in the case of the central control system's accident), software for prediction of phenomena (EMUT) - evidence of tunnel incidents.

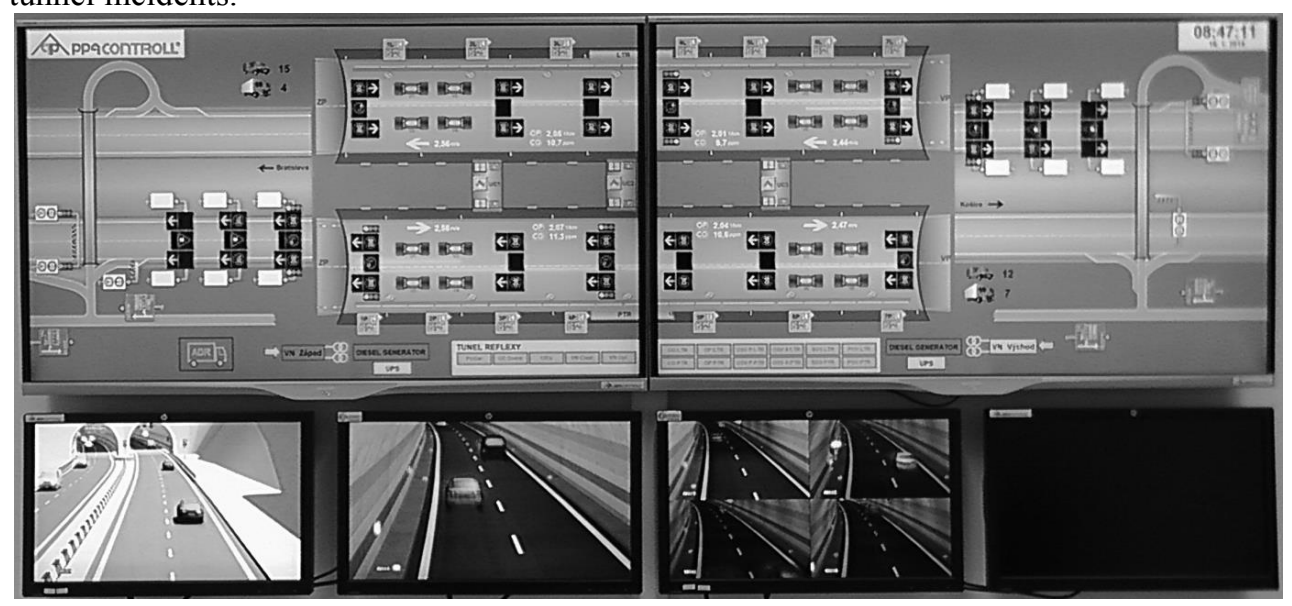

Fig. 1. Tunnel Traffic and Operation Simulator - operators' workplace monitors

Thanks to Tunnel Traffic \& Operation Simulator it is possible to verify operating conditions by real operation at the visualization on each operating condition. Verification of operators' response in operating conditions in the tunnel tube, also throughout a formation 
of fire, is possible only on the Tunnel Traffic \& Operation Simulator in the Transport Research Centre. In the case of operating condition with dangerous goods transportations vehicles it is very necessary and required by the TP 082 a preventive verifying of operators professional competence.

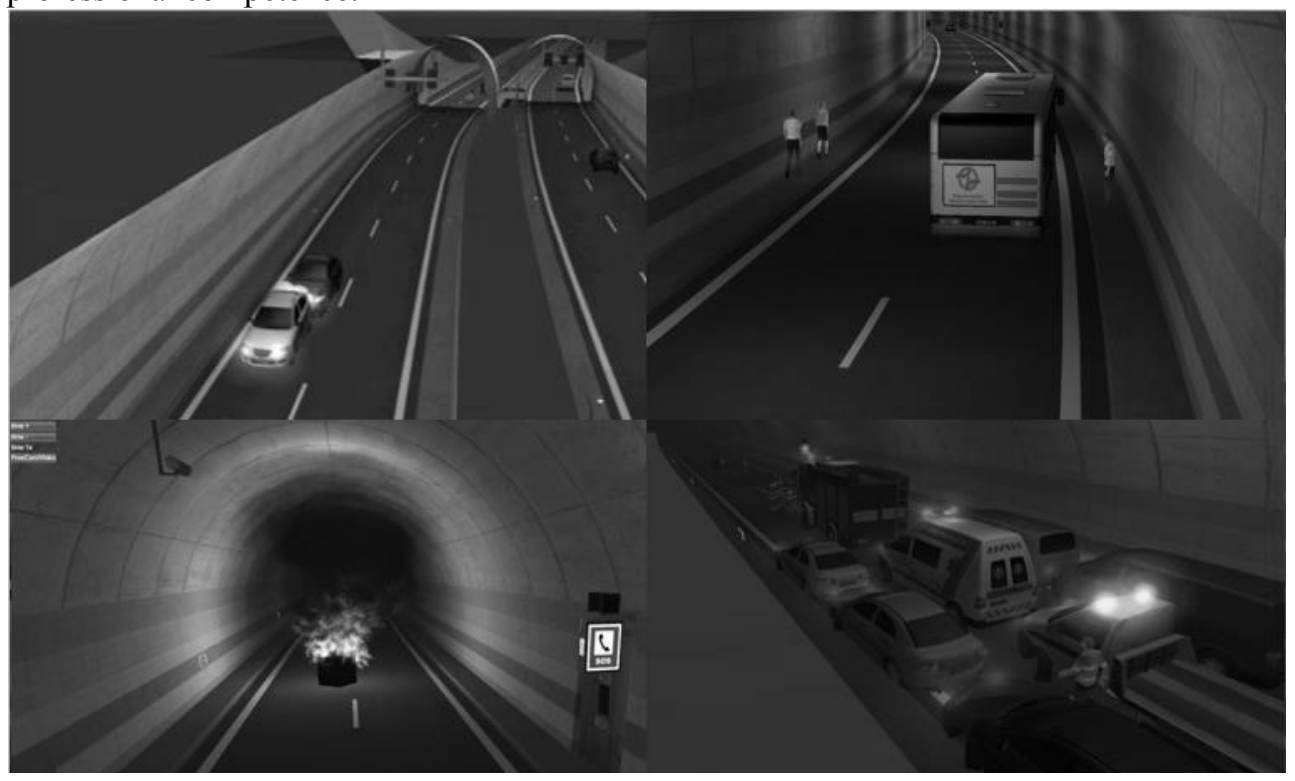

Fig. 2. Some possible simulations of various incidents

\subsection{Manual control module (MMR)}

The role of this operators and tunnel maintenance specialists department is to inform operators and reporters of data collection with any new technical and technological tunnel equipment following changes in tunnel operation legislation [3].

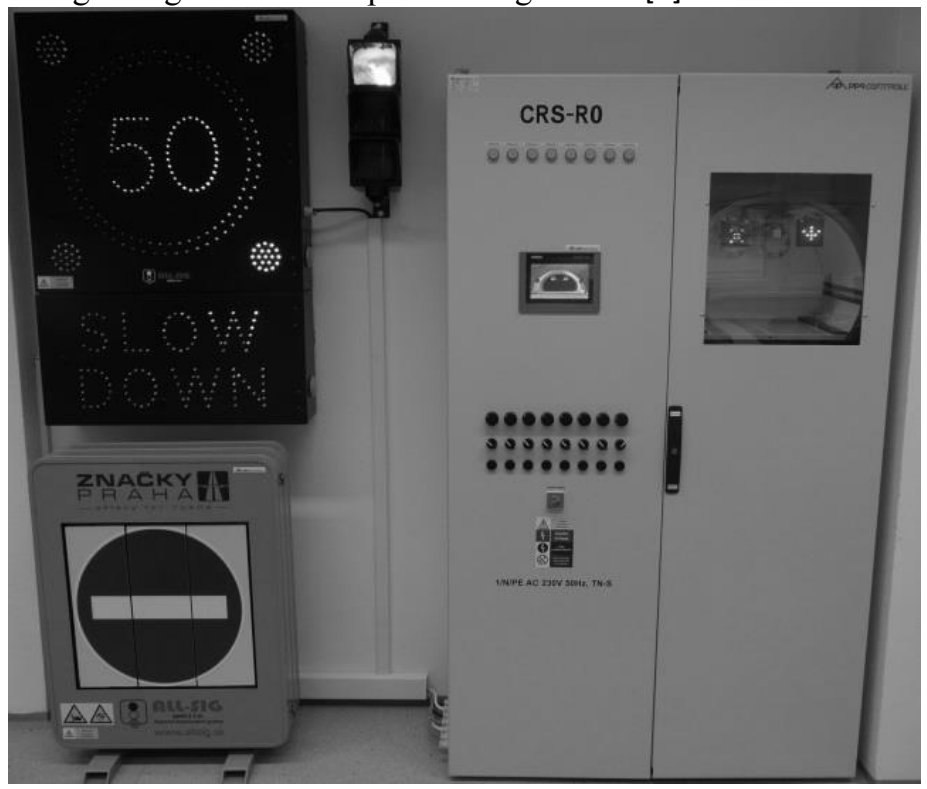

Fig. 3. Manual control module 


\subsection{Software for prediction of phenomena - EMUT}

EMUT is a special program for evidence and evaluation of incidents in the tunnel. It is registered every change compared to the tunnel's operating conditions under normal operating conditions, when an intervention of technology's operator and traffic's operator is not required. It is possible to create a graphic representation of incidents in tunnels at a different frequency assessment of a monitored parameter.

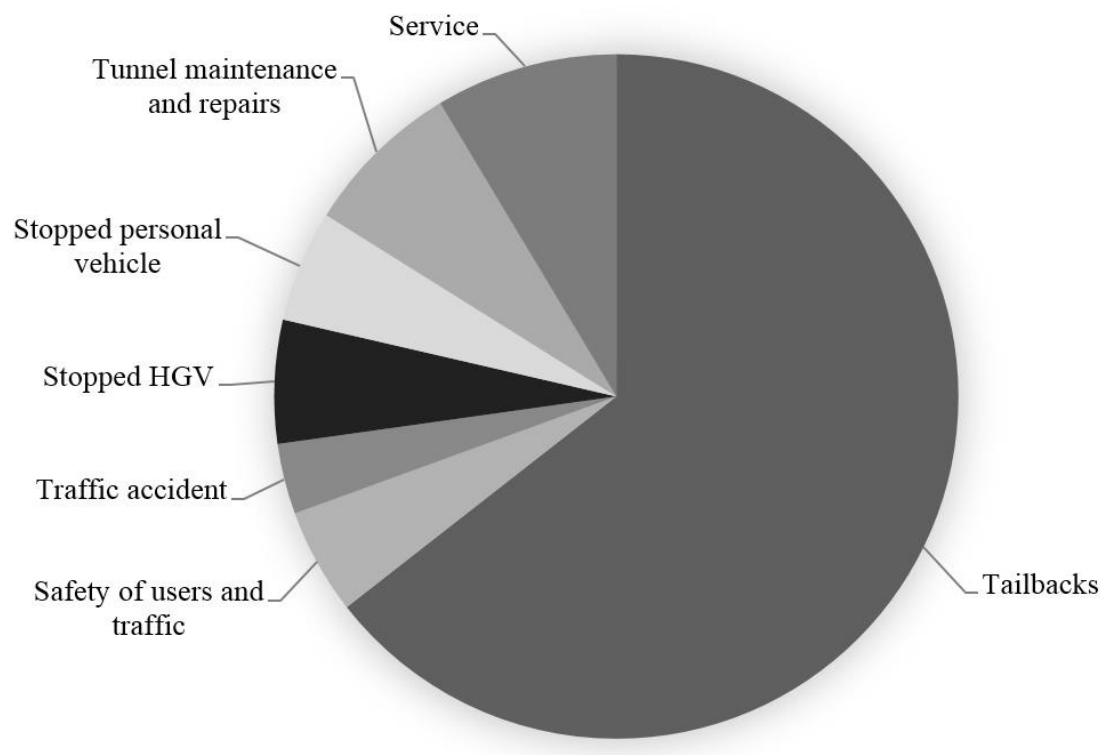

Fig. 4. Sectoral graph of events in a one tube tunnel (per year)

14

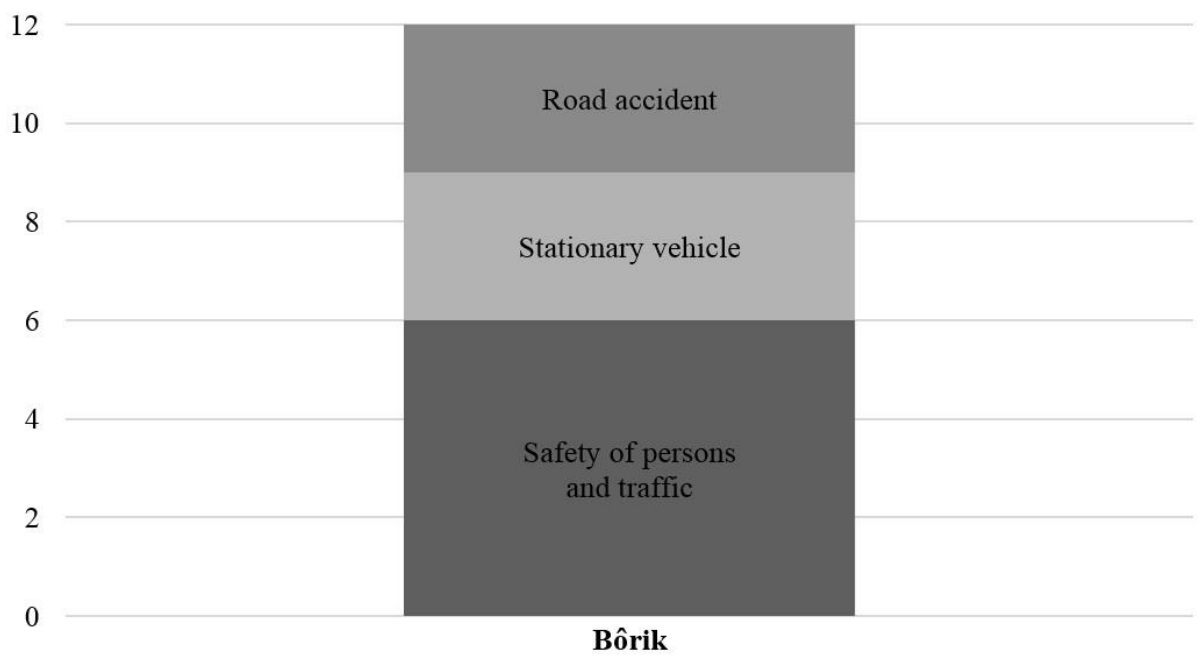

Fig. 5. The number of incidents in both tunnel tubes for a period of 1 month 


\section{Risk analysis}

The risk analysis of road tunnels in Slovakia is performed according to specifications TP 041 (02/2011) Risk Analysis for Slovak road tunnels. This regulation was created primarily to the definition of the exact methodology for risk analysis of the safety of road users in tunnels. For the calculation of risks in road tunnels is in TP precisely defined and explained the risk model, which was developed based on the Austrian model for risk analysis of tunnel TuRisMo [4].

Table 1. Overview of the Slovak tunnels in use [5]

\begin{tabular}{|c|c|c|c|c|c|}
\hline & Šibenik & Bôrik & Sitina & Horelica & Branisko \\
\hline Tunnel's length & $588 \mathrm{~m}$ & $995 \mathrm{~m}$ & $1440 \mathrm{~m}$ & $605 \mathrm{~m}$ & $4975 \mathrm{~m}$ \\
\hline $\begin{array}{l}\text { Number of } \\
\text { tunnel tubes }\end{array}$ & 2 & 2 & 2 & 1 & 1 \\
\hline Category & $2 \mathrm{~T} 8,0$ & $\mathrm{~T} 7,5$ & T 7,5 & T 9,0 & $\mathrm{T} 7,5$ \\
\hline Route & $\begin{array}{l}\text { Jánovce - } \\
\text { Jablonov }\end{array}$ & $\begin{array}{l}\text { Mengusov } \\
\text { ce - } \\
\text { Poprad, } \\
\text { západ }\end{array}$ & $\begin{array}{l}\text { BA, } \\
\text { Polianky - } \\
\text { BA, } \\
\text { Mlynská } \\
\text { dolina }\end{array}$ & $\begin{array}{l}\text { Oščadnica } \\
\text { - Čadca, } \\
\text { Bukov }\end{array}$ & $\begin{array}{l}\text { Beharovce } \\
\text { - ك̌́iroké }\end{array}$ \\
\hline $\begin{array}{l}\text { Start of } \\
\text { construction }\end{array}$ & $06 / 2012$ & $06 / 2006$ & $10 / 2003$ & 04/1998 & $05 / 1997$ \\
\hline Used since & $11 / 2015$ & $12 / 2009$ & $06 / 2007$ & $10 / 2004$ & $06 / 2003$ \\
\hline Traffic load & $\begin{array}{l}13573 \\
\text { veh/24h }\end{array}$ & $\begin{array}{l}12342 \\
\text { veh/24h }\end{array}$ & $\begin{array}{l}50351 \\
\text { veh/24h }\end{array}$ & $\begin{array}{l}13011 \\
\text { veh/24h }\end{array}$ & $\begin{array}{l}9433 \\
\text { veh/24h }\end{array}$ \\
\hline $\begin{array}{l}\text { The proportion } \\
\text { of passenger } \\
\text { vehicles }\end{array}$ & $75,00 \%$ & $80,13 \%$ & $87,90 \%$ & $68,96 \%$ & $75,24 \%$ \\
\hline $\begin{array}{l}\text { The proportion } \\
\text { of trucks }\end{array}$ & $23,08 \%$ & $18,21 \%$ & $11,41 \%$ & $30,52 \%$ & $23,14 \%$ \\
\hline $\begin{array}{l}\text { The proportion } \\
\text { of bus }\end{array}$ & $1,95 \%$ & $1,66 \%$ & $0,69 \%$ & $0,52 \%$ & $1,62 \%$ \\
\hline
\end{tabular}

Table 2. Accidents in highway tunnels.

\begin{tabular}{|c|c|c|c|}
\hline Tunnel & $\begin{array}{c}\text { Incident inside the } \\
\text { tunnel }\end{array}$ & Traffic intensity & $\begin{array}{c}\text { Number of } \\
\text { accidents/1 million of } \\
\text { vehicle } \mathbf{~ k m}\end{array}$ \\
\hline Horelica & 6 & 13011 & 0,19 \\
\hline Bôrik & 6 & 9433 & 0,30 \\
\hline Branisko & 30 & 12342 & 0,11 \\
\hline Sitina & 56 & 50350 & 0,27 \\
\hline
\end{tabular}

Statistics for tunnel Šibenik are not available yet for because a short time of its use. 
Table 3. Risk analysis values of Slovak tunnels in use [6].

\begin{tabular}{|l|c|c|}
\hline Tunnel & $\begin{array}{c}\text { Statistically expected value of the } \\
\text { number of death toll per year }\end{array}$ & Danger Category \\
\hline Branisko & 0,2156 & III \\
\hline Horelica & 0,0705 & II \\
\hline Bôrik & 0,0529 & II \\
\hline Sitina & 0,2327 & III \\
\hline Šibenik & 0,0361 & II \\
\hline
\end{tabular}

The basic number of accidents in tunnels in Slovakia with two-way traffic is 0,025 and with one-way traffic is 0,036 accidents/1million of vehicle $\mathrm{x} \mathrm{km}$. Just for comparison with some EU countries, in Czech Republic this number is 0,312, in Germany 0,228 and in Austria 0,0112 accidents/1million of vehicle $\mathrm{x} \mathrm{km}$ (updated in 09/2015).

\section{Conclusion}

One of the primary objectives of each tunnel is to advance the high level of traffic and users safety. Therefore, it is crucial to do the necessary engineering adjustment and install special technological equipment designed to improve a safety. Compared to the accidents on the roads outside the tunnel, even a minor incident in the tunnel can escalate to catastrophic proportions. So it is important to optimize and simplify the security system of the tunnel to limit the possible human or technical error. The objective of the system is to communicate early and reliably all the necessary information about the current status of traffic conditions in the tunnel and to allow a safe evacuation of users from the tunnel in the case of an accident. The Tunnel Traffic \& Operation Simulator in our University of Žilina is used for simulating critical events in road tunnels. We can simulate the various incidents and they can serve for prediction of these events in real tunnels.

\section{Acknowledgement}

"This work was supported by the Slovak Research and Development Agency under the contract No. APVV-15-0340".

This contribution is the result of the project implementation: "Centre of Transport Research" (ITMS 26220220135) supported by the Research \& development Operational Programme funded by the ERDF.
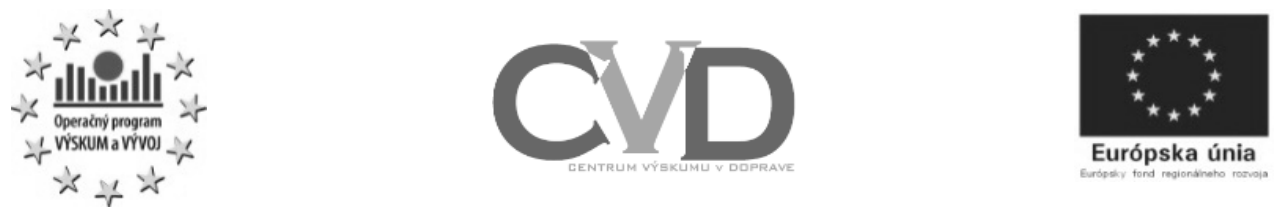

"We support research activities in Slovakia/project co-founded from the resources of the EU" 


\section{References}

1. http://svf.uniza.sk/cvd/index.php

2. http://www.uniza.sk/menu/inc.php?id=9

3. P. Danišovič, Š. Šedivý, M. Rázga, E. Jančaříková, Tunnel Traffic \& Operation Simulator (13th International Conference Underground Construction Prague 2016, Czech Republic)

4. TP 041 (02/2011) Risk Analysis for Slovak road tunnels (in origin: Analýza rizík pre slovenské cestné tunely) (technical specifications, 2011)

5. http://www.ndsas.sk/tunely-nds/44745s

6. M. Rázga, Technical and technological aspects of road tunnels operation safety (in origin: Technické a technologické aspekty bezpečnosti prevádzky dialničných tunelov) (PhD. thesis, University of Žilina, 2016) 